\title{
Anillos de Dumbar: un raro signo radiológico
}

\author{
Ascaso Til H, Segarra Tomás J, Arce Gil J, Alberola Bou J*, Millán Rodríguez F, \\ Villavicencio Mavrich $\mathrm{H}$.
}

Servicio de Urología, *Servicio de Radiología. Fundació Puigvert. Barcelona.

\section{Actas Urol Esp. 2008;32(6);671}

T os anillos de Dumbar o signo de la semiluna son Uun signo radiológico de obstrucción renal crónica, que se visualiza adecuadamente en la fase nefrográfica de la urografía intravenosa (UIV). Los túbulos intramedulares llenos de contraste, pero distorsionados por la obstrucción mantenida, al situarse en paralelo al contorno calicial dan una imagen de anillo o semiluna.

Presentamos el caso de una mujer de 40 años, sin antecedentes de interés que acude a nuestro centro para valoración de litiasis renal izquierda de larga evolución. Aporta UIV (Fig. 1) donde se observa retraso funcional del riñón izquierdo, con litiasis coraliforme que ocupa pelvis y grupos calicilares inferior y medio con dilatación de grupos calicilares inferior y superior, compatible con el signo de anillos de Dumbar. Los mismos hallazgos se observan en el TC abdominal (Fig. 2). La gammagrafía renal DMSA muestra un riñón izquierdo de tamaño disminuido y que aporta un $4 \%$ al funcionalismo renal global, por lo que se indicó nefrectomía izquierda.

Correspondencia autor: Dra. H. Ascaso Til Servicio de Urología. Fundació Puigvert. Cartagena, 340-350 - 08025 Barcelona Tel.: 934169700

E-mail autor: hascasotil@yahoo.es Información artículo: Imágenes en Urología Trabajo recibido: enero 2007

Trabajo aceptado: febrero 2007

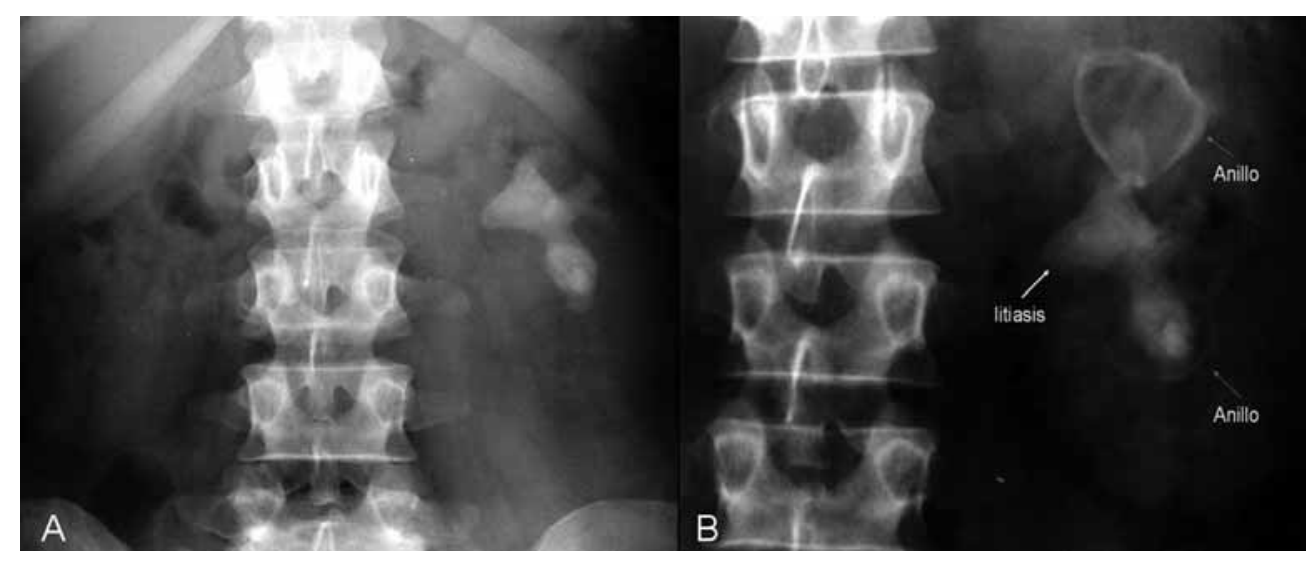

FIGURA 1. A) Rx simple de abdomen: litiasis coraliforme izquierda. B) UIV: Se observa la litiasis coraliforme, que ocupa pelvis, grupo calicilar medio $e$ inferior, y los anillos de Dumbar, como expresión de obstrucción crónica.

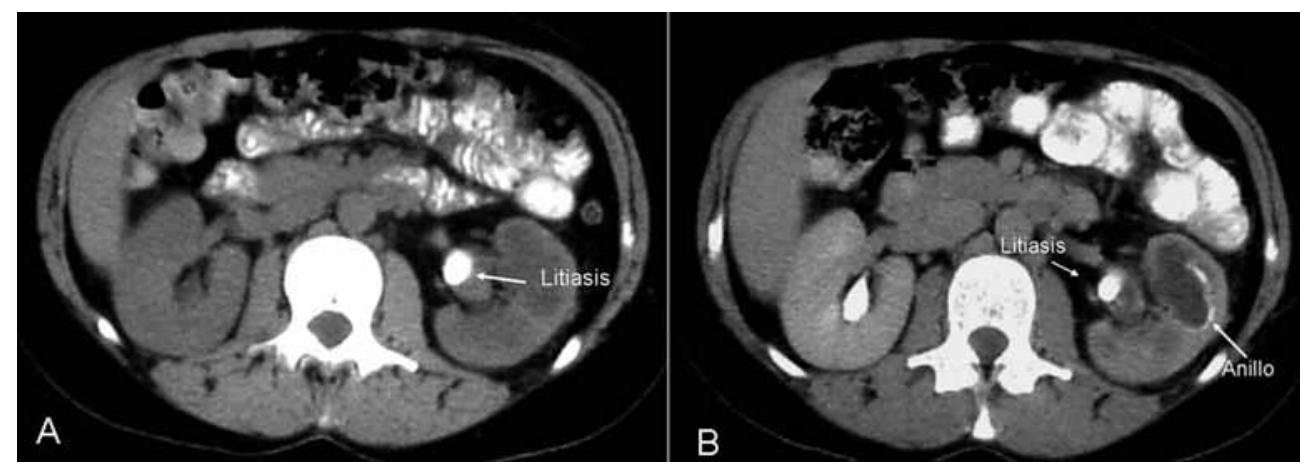

FIGURA 2: A) TC abdominal sin contraste, que muestra litiasis y ectasia renal izquierda. B) TC con contraste que muestra la disposición en forma de semiluna del mismo. 